\title{
PAMPA BIOME ENVIRONMENTAL PARTICULARITIES REGARDING TO ENERGY BALANCE
}

\author{
N. S. Rocha ${ }^{1, *}$, P.S. Käfer ${ }^{1}$, D. Skokovic ${ }^{2}$, G. Veeck ${ }^{3}$, L. R. Diaz ${ }^{1}$, E. Kaiser ${ }^{1}$, C. M Carvalho ${ }^{4}$, B.K.Veettil ${ }^{5,}{ }^{*}$, S. T. L. Costa ${ }^{1}$, R. \\ C. Cruz ${ }^{4}$, D. Robérti ${ }^{3}$, S. B. A. Rolim ${ }^{1, *}$ \\ ${ }^{1}$ UFRGS (Federal University of Rio Grande do Sul), Laboratório de Sensoriamento Geológico (LabSRGeo), Postgraduate in Remote \\ Sensing, Porto Alegre (RS), Brazil - najila.rocha@ufrgs.br \\ ${ }^{2}$ UV (University of Valencia), Unidad de Cambio Global (UCG), Image Processing Laboratory (IPL), Valencia, Spain.
}

${ }^{3}$ UFSM (Federal University of Santa Maria), Department of Physics, Santa Maria (RS), Brazil

${ }^{4}$ UNIPAMPA (Federal University of Pampa), Laboratorio Interdisciplinar de Ciências Ambientais (LICA), São Gabriel (RS), Brazil.

${ }^{5}$ Institute of Fundamental and Applied Sciences, Duy Tan University, Ho Chi Minh City 700000, Vietnam -

bijeeshkozhikkodanveettil@duytan.edu.vn

KEY WORDS: Native grassland, Evapotranspiration, LST, NDVI, Thermal Infra-red, Remote Sensing

\begin{abstract}
:
Ecosystem evapotranspiration (ET) has been quantified around the world by different methodologies to understand the energy balance, especially to control the evolution of climate change. It is known that the vegetation of the pampa biome is natural grasslands, it has a large variety of species (flora and fauna), however is it different in the environmental aspects related to the energy balance when compared to the grassland cultivated? In this study the objective was to analyze the environmental differences of the Pampa Biome related to the energy balance in comparison with the pastures cultivated in Barrax, Spain. In the first one the minimum daily ET is $0.99 \mathrm{~mm} /$ day, while in the second is $1.57 \mathrm{~mm} /$ day. However, the highest differences between the sites occur during the summer period, in the maximum daily ET, the maximum is $16.25 \mathrm{~mm} /$ day in Pampa and in Barrax is $7.31 \mathrm{~mm} / \mathrm{day}$. The results of this study have indicated that the characteristics of the Pampa biome, both in terms of soil and climatic issues and land use, generate differences in the energy balance when compared to similar vegetation in other regions of the world.
\end{abstract}

\section{INTRODUCTION}

Pampa biome is the only large natural area restricted to a single Brazilian state and it is considered a peculiar ecosystem. This biome advances to Uruguay and Argentina, thus being unique to southern South America (Cruz and Guadagnin, 2010; Santos and Trevisan, 2009).

In Brazil, the Pampa occupies more than 178 thousand $\mathrm{Km}^{2}$, which corresponds to more than $60 \%$ of the Rio Grande do Sul State territory and around $2 \%$ of the whole country. The region is frequently known as an ecologically poor region. Nevertheless, this is information disseminated and propagated by the "common sense". In fact, Pampa is rich in vegetation and fauna, with varied ecosystems, such as capoeiras, "pampa" forests and riparian forests.

According to the Map of Brazilian Biomes, it is one of the richest in geoecological configuration, mainly because it includes several microecosystems. In addition to the natural grasslands, it has a large variety of species (flora and fauna), which compose a peculiar landscape, said as "a sea of living green” (Overbeck et al., 2015; Santos and Trevisan, 2009).

Cruz and Guadagnin (2010) mention that the most important Pampa microecosystems are the watersheds, fundamental for the life reproduction and water cycles regulation and the riparian or gallery forests, which serve as refuge for a diverse fauna. In this context, Overbeck et al. (2015) point out that once Pampa ecosystems have their own characteristics, the simple quantification of being larger or smaller than a tropical forest biodiversity, becomes meaningless. For biodiversity purposes, what matters is the unique and irreplaceable biodiversity of each biome. The Pampa biome suffers from economic and social demands that modify its ecosystem, in addition the climate changes have modified the behavior of environmental variables and may also be causing a huge impact on this biome.

Ecosystems evapotranspiration (ET) has been quantified around the world by different methodologies to understand the energy balance and hydrological cycle and its variation, mostly to control of the evolution of climate change. In this way, the Pampa biome has been characterized by the quantification of ET and its relationship with environmental variables, especially when it comes to the validation of ET by remote sensing (Fontana et al., 2018; Monteiro et al., 2014; Rubert et al., 2018).

It is already known that the vegetation of the pampa biome is unique in the world, but is it distinct in the environmental aspects concerning the energy balance when compared to grassland cultivated vegetation around the world? To understand that in this preliminary study the objective was to analyze the Pampa Biome environmental differences related to 
the energy balance in comparison to the grasslands cultivated in Barrax, Spain.

\subsection{Study area}

Two different test areas have been used in this study. One of them in Brazilian Pampa Biome and another one in Barrax site located in the west of Albacete province, Spain (Figure 1). They were select because, firstly, they have the same kind of vegetation and, secondly, they have a continuous meteorological monitoring. Beside of that it was in Barrax that the ET model test in this work was performed and validated.

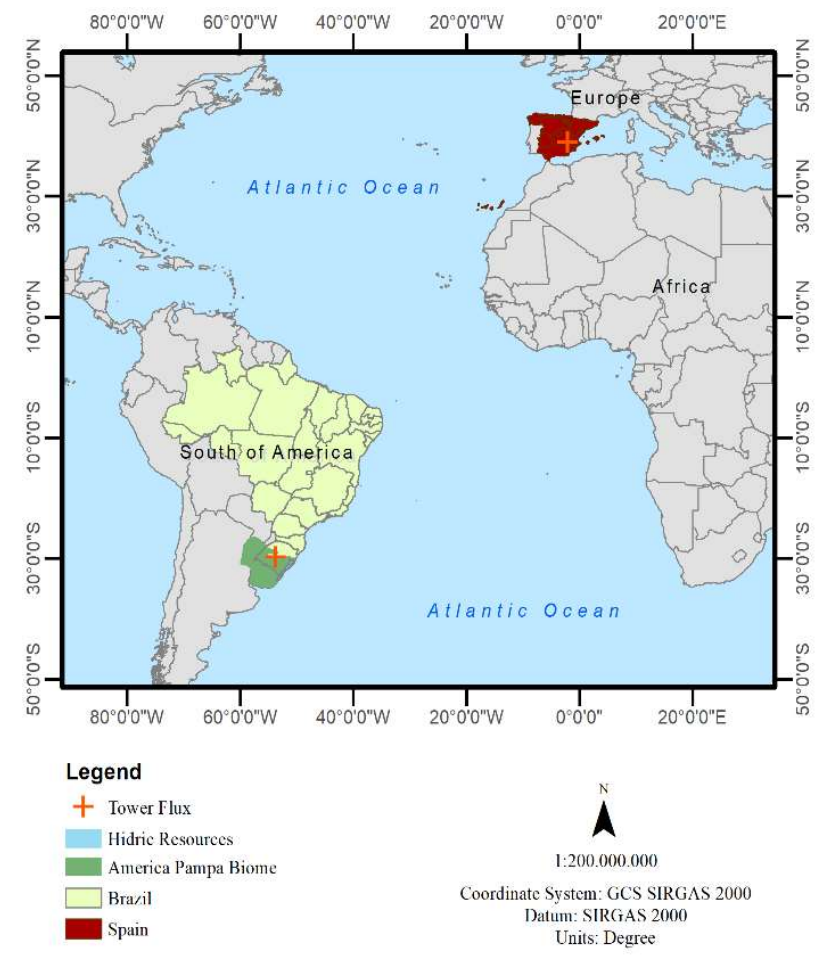

Figure 1. Experimental site locations in Pampa Biome (Brazil) and Barrax (Spain) site

The analyses in the Pampa Biome were performed in the experimental area of the Federal University of Santa Maria (UFSM) with native grassland (Figure 2a). In this area there is a Tower Flux under the responsibility of the Micrometeorology Laboratory of UFSM, which provided some important variables used in this work. This study area is part of the International Long Term Ecological Research (ILTER) network and is used for experiments of the UFSM in several areas of knowledge, mainly focused on the morphology of native species for livestock production (Confortin et al., 2017; Oliveira et al., 2015).

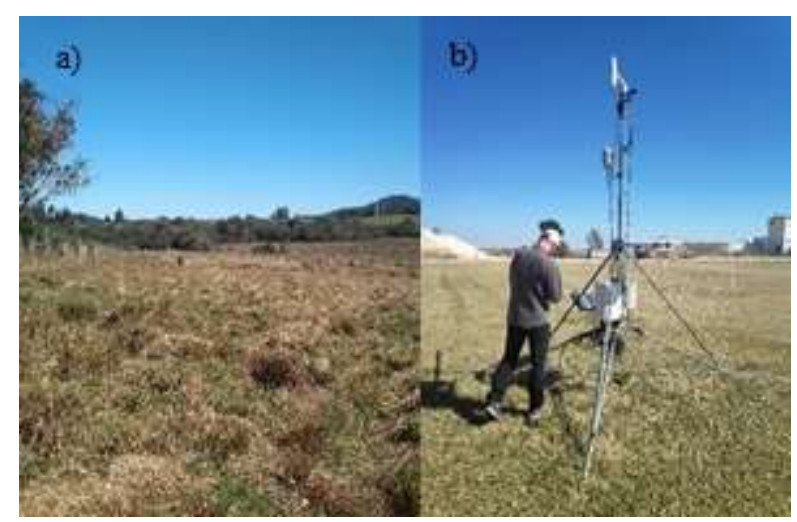

Figure 2. a) Santa Maria experimental site with native grassland; b) Barrax experimental site with cultivated grassland.

In Spain, this study was performed in Barrax site which is an experimental area selected in many field campaigns for calibration/validation activities because of its flat terrain and the presence of large, uniform land-use units (approximately 100 ha), suitable for validating moderate-resolution satellite image products. Figure $2 \mathrm{~b}$ shows a fixed station over grassland cultivated field with continuous LST measurements taken by a radiometer that covers a footprint of $3 \mathrm{~m}^{2}$ (Sobrino and Skoković, 2016).

In addition to differences in land use and land cover, there are some climatic differences between those two study areas: 1) The annual average temperature of the Pampa Biome varies between $16^{\circ} \mathrm{C}$ and $18{ }^{\circ} \mathrm{C}$ and the precipitation between 1,500 $\mathrm{mm}$ and 1,600 $\mathrm{mm}$ (Neske et al., 2012). The climate of the study region is characterized by great homogeneity and is controlled by various factors such as latitude, geomorphology, South Atlantic subtropical anticyclone and ocean currents (Hoffmann et al., 1997). Furthermore, this region is constantly subject to sudden changes in weather caused by the passage of the polar front (Nimer, 1990). Due to its position between the mid-latitudes of the subtropics, the climate is of temperate type, which gives an important thermal oscillation throughout the year with a cold winter and a hot summer (Nimer, 1990). 2) In Barrax area there is a Mediterranean climate with heaviest rainfalls in Spring and Autumn and lowest in Summer. The rainfall statistics show that the mean annual rainfall is little more than $400 \mathrm{~mm}$ in most of the area, making La Mancha one of the driest regions in Europe (Gómez et al., 2005; Sobrino et al., 2005).

\section{METHODOLOGY}

\subsection{Data Acquisition}

Ten images from Landsat 8 were acquired, five for each site, to the year 2018, and treated with geometric rectification and clipped using a study area border. Radiometric calibration and atmospheric correction procedures were conducted to ensure that the change detection analyzes truly detected changes at the Earth's surface rather than at the sensor level, solar illumination differences, and potential differences in atmospheric conditions. 
From the tower flux we have been acquired the global incident solar radiation $(R g)$ and the incident atmospheric radiation over the spectral domain $(R a)$, obtained with the satellite overpass (Table 1).

\begin{tabular}{|l|l|l|l|}
\hline Acquisition Date & Season & DOY & Site \\
\hline 16 Dec 2018 & Summer & 349 & Pampa \\
29 Nov 2018 & Winter & 332 & Barrax \\
25 Aug 2018 & Summer & 236 & Barrax \\
26 Aug 2018 & Winter & 237 & Pampa \\
15 Jun 2018 & Summer & 165 & Barrax \\
06 Jul 2018 & Winter & 186 & Pampa \\
19 Apr 2018 & Spring & 108 & Barrax \\
04 Apr 2018 & Autumn & 93 & Pampa \\
23 Feb 2018 & Winter & 53 & Barrax \\
15 Feb 2018 & Summer & 45 & Pampa \\
\hline
\end{tabular}

Table 1. Satellite Landsat 8 OLI/TIRS data by each day of year (DOY) to Pampa Biome

\subsection{Data Processing}

shows the algorithms used to calculate Normalized Difference Vegetation Index (NDVI), Albedo ( $\alpha$ ), Soil Heat Flux (G), Land Surface Temperature (LST) and Land Surface Emissivity (LSE). Those indices have been used to estimate the balance energy by remote sensing.

Where:

Table 2

\begin{tabular}{|c|c|}
\hline Variable & Equation \\
\hline NDVI & $\begin{array}{l}\quad(\rho \mathrm{NIR}-\rho \mathrm{RED}) /(\rho \mathrm{NIR}+\rho \mathrm{RED}) ;{ }^{(1)} \\
\text { (Rouse et al., 1973) }\end{array}$ \\
\hline Albedo $(\alpha)$ & $\begin{array}{l}0.365 \mathrm{~b} 2+0.130 \mathrm{~b} 4+0.373 \mathrm{~b} 5+0.085 \mathrm{~b} 6 \\
+0.072 \mathrm{~b} 7-0.0018 ; \text { (Liang, 2000; Liang et al., } \\
\text { 1998). }\end{array}$ \\
\hline $\begin{array}{l}\text { LSE and } \\
\text { LST }\end{array}$ & $\begin{array}{l}\quad \mathrm{Ti}-0.268(\mathrm{Ti}-\mathrm{Tj})+1.378(\mathrm{Ti}-\mathrm{Tj})^{2}+ \\
16.4+(0.183+54.3 \mathrm{w})(1-\varepsilon)+(-2.238- \\
129.2 \mathrm{w}) \Delta \varepsilon ;{ }^{(2)} \\
\quad \text { (Jimenez-Munoz et al., 2014; Sobrino et } \\
\text { al., 1996) }\end{array}$ \\
\hline $\begin{array}{l}\text { Soil Heat } \\
\text { Flux }(G)\end{array}$ & $\begin{array}{l}\left((\mathrm{Ts} / \alpha) *\left(0.0038^{*} \alpha\right)+\left(0.0074 * \alpha^{2}\right) *(1-\right. \\
\left.\left.0.98 * \mathrm{NDVI}^{4}\right)\right) * R n ;(\text { Bastiaanssen, 2000) }\end{array}$ \\
\hline
\end{tabular}

Table 2. Equations used to the pre-processing image data
(1) $\rho$ NIR and $\rho$ RED are calculated using Landsat 8 channel 5 (0.86) and channel $4(0.65)$;

(2) $T i$ and $T j$ are the at-sensor brightness temperatures at the SW bands $i$ and $j$ (in kelvins), $\varepsilon$ is the mean emissivity, $\varepsilon=0.5$ ( $\varepsilon i+$ $\varepsilon j), \Delta \varepsilon$ is the emissivity difference, $\Delta \varepsilon=(\varepsilon i-\varepsilon j), w$ is the total atmospheric water vapor content (in $\mathrm{g} / \mathrm{cm}-2$ ), and $c 0$ to $c 6$ are the Split Window (SW) coefficients to be determined from simulated data.

\subsection{Method}

We used S-SEBI model to obtain instantaneous latent heat flux (LET) for all acquired images (Roerink et al., 2000). The surface energy balance is obtained by determining the magnitude of the radiative and non-radiative fluxes. It is written as follow, when considering instantaneous condition.

$$
R n=L E T+G,
$$

Where:

$R n\left(W m^{-2}\right)$ is the available net radiation flux,

$G\left(W m^{-2}\right)$ is the soil heat flux (see Table 2),

LET $\left(\mathrm{W} \mathrm{m}^{-2}\right)$ is the latent heat flux (both atmospheric convective fluxes: sensible heat flux and latent energy exchanges).

Once the surface energy balance equation is discriminated, the $R n$ is calculated as the rest term of all incoming and outgoing shortwave (sw) and longwave (lw) radiation, as describing below:

$$
R n=(1-\alpha) R g+\varepsilon R a-\varepsilon \sigma L S T^{4},
$$

Where:

$\operatorname{Rg}\left(\mathrm{W} \mathrm{m}^{-2}\right)$ is the global incident solar radiation;

$R a\left(W^{-2}\right)$ is the incident atmospheric radiation over the thermal spectral domain;

$\alpha$ is the surface albedo;

$\varepsilon$ is the surface emissivity;

LST (Kelvin) is the land surface temperature;

$\sigma$ is the Steffan-Boltzmann constant $\left(5.67 \times 10-8 \mathrm{~W} \mathrm{~m}^{-2}\right.$ $\left.K^{-4}\right)$.

The latent heat flux (LET) depends on the evaporative fraction $(\Lambda)$ and is given as follow.

$$
L E T=\Lambda(R n-G)
$$

The evaporative fraction concept $(\Lambda)$ was proposed by (Roerink et al., 2000), adapted and tested by (Sobrino et al., 2007, 2005), and it is described by the equation below. 


$$
\Lambda=\frac{T_{H}-L S T}{T_{H}-T_{L E}}
$$

Where:

$\mathrm{T}_{H}(\mathrm{~K})$ is the temperature corresponding to dry conditions;

$\mathrm{T}_{L E}(\mathrm{~K})$ is the temperature corresponding to wet condition.

The S-SEBI model should be only applied when the atmospheric conditions are constants over the image and the study site includes simultaneously wet and dry areas (Roerink et al., 2000; Sobrino et al., 2007, 2005). Besides of that, this method works better in a homogeneous vegetated area - with higher variance between dry and wet pixels.

\subsection{Daily Evapotranspiration}

Daily evapotranspiration is defined as the temporal integration of ET instantaneous values in a day. It was performed using the relationship between the daily net radiation flux $\left(R_{n d}\right)$ and instantaneous radiation flux $\left(R_{n i}\right)$. This concept was tested by the authors and it is called $C_{d i}$ (Gómez et al., 2005; Sobrino et al., 2007). In this context the authors have created an expression to calculate the $C_{d i}$ from each image DOY and in this study, to make the process more operational and reapplied, we have used the same expression as described below.

$$
C_{d i}=-7 \mathrm{e}^{-6} *\left(\mathrm{DOY}^{2}\right)+(0.0026 * \mathrm{DOY}+0.0756)
$$

Where:

$C_{d i}$ is the relationship between the daily net radiation flux $\left(R_{n d}\right)$ and instantaneous radiation flux $\left(R_{n i}\right)$;

DOY is Day of the Year (see Table 1).

\section{RESULTS AND DISCUSSION}

In Figure 3 we can observe the temporal variation of daily evapotranspiration throughout the year 2018 for both areas of study. In the Pampa Biome the minimum daily ET is 0.99 $\mathrm{mm} /$ day, while in Barrax is $1.57 \mathrm{~mm} /$ day. However, the highest differences between the sites occur in the maximum daily ET, in Pampa Biome the maximum is $16.25 \mathrm{~mm}$ /day in December (summer season) and in Barrax is $7.31 \mathrm{~mm}$ /day in August (summer season). Also, in Pampa Biome the difference between the minimum and maximum ET is greater than in Barrax. According to Fontana et al., (2018) this variability influences all types of vegetation growth and, in the Pampa biome, causes variations in the forage availability to the animals throughout the seasons and also years.

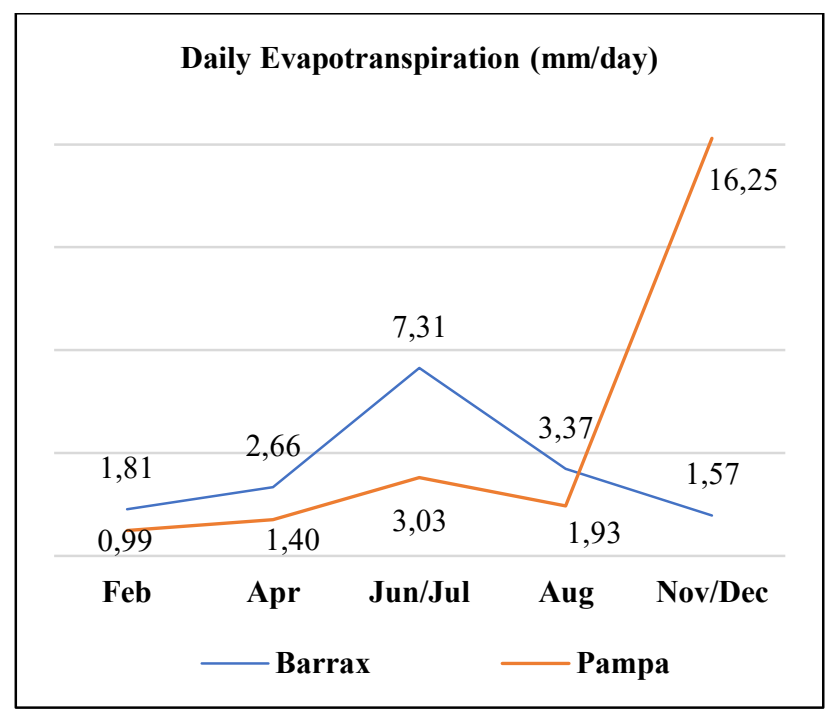

Figure 3. Daily Evapotranspiration for both Pampa Biome and Barrax site

Rubert et al., (2018) have also analyzed the Pampa biome ET by eddy co-variance and have concluded that this biome presented strong seasonality of evapotranspiration, with the highest evapotranspiration rates in the summer season, where the vegetation was in active growth and, therefore, had higher biomass production. The results of this study agree with the authors and indicate that the characteristics of the Pampa biome, both in terms of soil and climatic issues and land use, generate differences in the energy balance when compared to similar vegetation in other regions of the world.

The environmental differences between Pampa and Barrax can be observed in Table 3, the table shows the variables values in the tower flux point for both areas. It can be observed that in a cultivated grassland area (Barrax) there is a higher seasonal difference in LST $(24 \mathrm{~K})$ compared to the native grassland (Pampa) LST (13.92 K). This can be explained by the temporal distribution of rainfall throughout the year in Rio Grande do Sul State. According to IPCC (2013) these distribution will change in South of America and precipitation tends to be more concentrated in rainy months. So, it is possible infer that LST behaviour in this area will also change significantly.

\begin{tabular}{|ccccc|}
\hline Variable & \multicolumn{2}{c}{ Daily ET $(\mathbf{m m} / \mathbf{d a y})$} & \multicolumn{2}{c|}{ NDVI } \\
\hline Season & Pampa & Barrax & Pampa & Barrax \\
Winter & 2,48 & 1,69 & 0,54 & 0,59 \\
Summer & 8,62 & 5,34 & 0,74 & 0,65 \\
\hline Variable & & Albedo & \multicolumn{2}{c|}{ LST (K) } \\
Season & Pampa & Barrax & Pampa & Barrax
\end{tabular}




\begin{tabular}{|ccccc|} 
Winter & 0,17 & 0,19 & 288,31 & 285,81 \\
& & & & \\
Summer & 0,18 & 0,19 & 302,28 & 310,75 \\
\hline
\end{tabular}

Table 3. Environmental variables differences between Pampa Biome site and Barrax site.

A higher temporal variability of NDVI in Pampa is consistent with a higher spatial and temporal variability of the vegetation that composes the Pampa biome natural grasslands discussed by Overbeck et al., (2007). That is why NDVI can be used as indicators of the vegetation growth and development and are associated with the subtropical climate prevailing in the region. (Fontana et al., 2018).

\subsection{Analyses for entire image}

In Figure 4 is possible to compare the spatial variability of daily ET to Barrax site and in Figure 5 we can see the daily ET to Pampa, both in winter season. In the first one, most of the pixels (area) have around $3 \mathrm{~mm} /$ day of ET. In the second one, most of the area have between $5 \mathrm{~mm} /$ day and $7 \mathrm{~mm} /$ day of evapotranspiration.

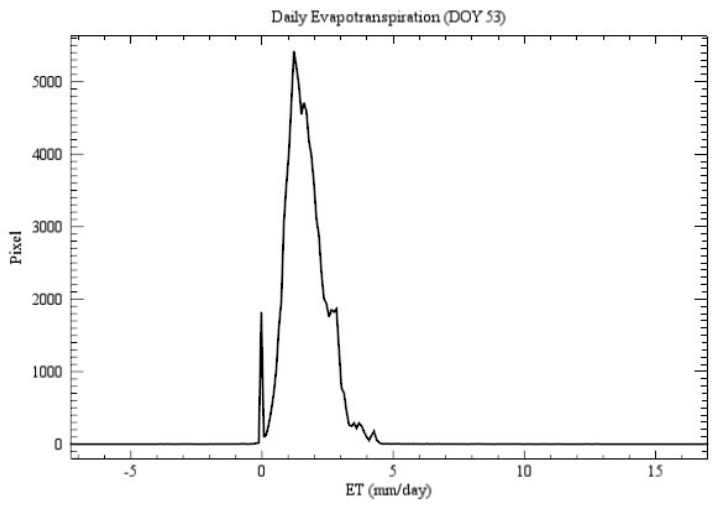

Figure 4. Daily Evapotranspiration (mm/day) graphic distribution for Barrax in winter season (DOY 53)

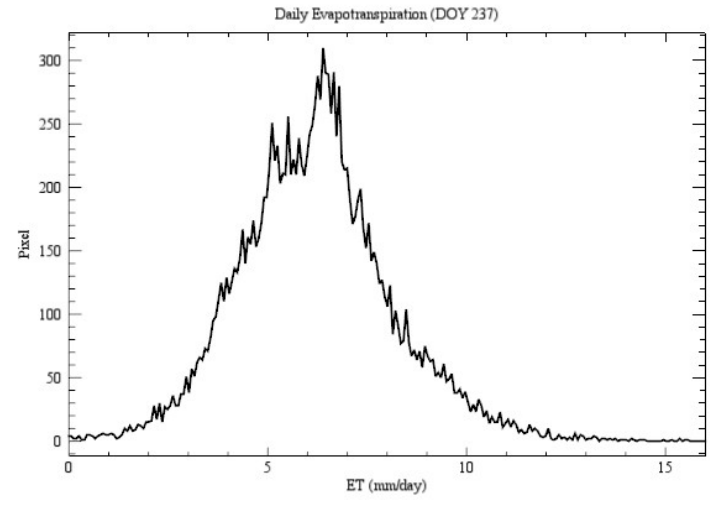

Figure 5. Daily Evapotranspiration (mm/day) graphic distribution for Pampa Biome in winter season (DOY 237) In summer period this spatial heterogeneity of ET to Pampa is higher than in winter season. In order to understand better the behaviour of evapotranspiration in the Santa Maria site compared to Barrax, Figure 6 presents the graph of mean, minimum and maximum values extracted from the clipping of the image. It is possible to say that although it is known that there is a difference in daily evapotranspiration during the year for the different types of vegetation cover for both sites, mainly in the summer months, the landscape of the Pampa biome in this study is more heterogeneous in terms of energy when compared to the Barrax study site.

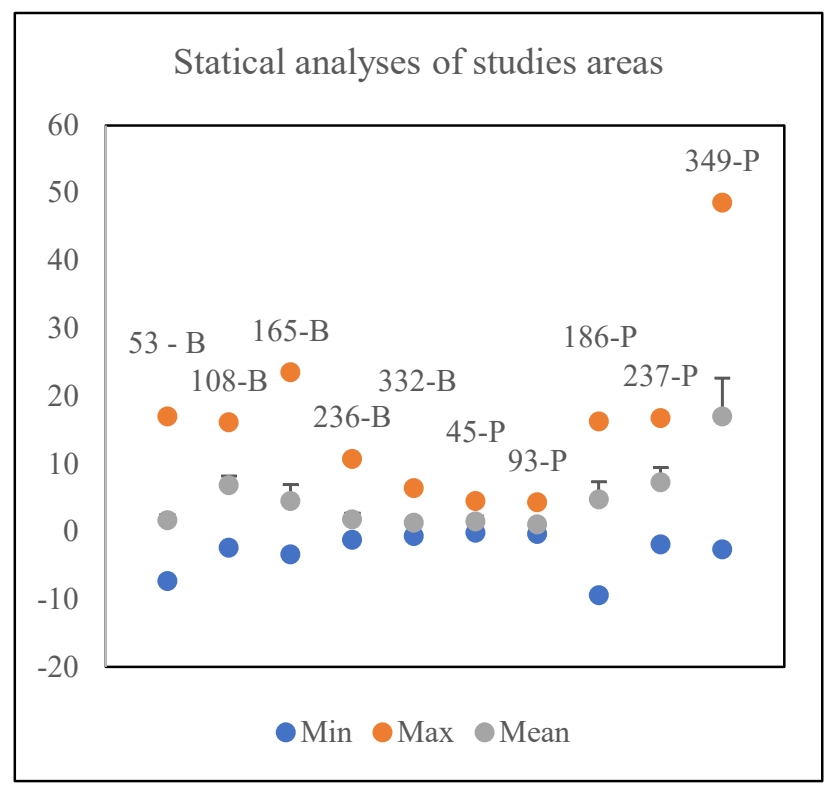

Figure 6. Statistical analyses of the images studied for each Day ff the Year (DOY). Where " $\mathrm{P}$ " is Pampa Biome and " $\mathrm{B}$ " is Barrax

Obviously, we know that the differences between the two validation sites are not only in the type of vegetation, but the meteorological and environmental conditions also influence the available amount of energy for evapotranspiration.

\section{CONCLUSIONS}

The Pampa Biome is unique in the world, distancing itself in all known environmental aspects. This work sought to understand how these particularities influence the evapotranspiration of the native grassland vegetation of the pampa biome and what the differences are when compared to the grassland cultivated in Spain.

The results indicate differences in two variables studied: LST and NDVI. In a cultivated grassland area, there is a higher seasonal difference in LST compared to the native grassland. Moreover, a higher temporal variability of NDVI in Pampa is consistent with a higher spatial and temporal variability of the vegetation that composes the Pampa biome natural grasslands.

The results presented in this preliminary study indicate that the properties of the Pampa biome generate differences in the energy balance when compared to similar vegetation in other regions of the world. For further studies we have recommended that other variables are included in the analyses, such as: precipitation, air temperature and soil heat flow.

\section{ACKNOWLEDGEMENTS}

This study was financed in part by the Coordenação de Aperfeiçoamento de Pessoal de Nivel Superior - Brazil (CAPES), finance code 001, and by the Fundação de Amparo a Pesquisa do Rio Grande do Sul (FAPERGS). 


\section{REFERENCES}

Bastiaanssen, W.G.M., 2000. SEBAL-based sensible and latent heat fluxes in the irrigated Gediz Basin, Turkey. J. Hydrol. 229, 87-100. https://doi.org/10.1016/S0022-1694(99)00202-4

Confortin, A.C.C., Quadros, F.L.F., Santos, A.B., Seibert, L., Severo, P.O., Ribeiro, B.S.R., 2017. Leaf tissue fluxes of Pampa biome native grasses submitted to two grazing intervals. Grass Forage Sci. 72, 654-662. https://doi.org/10.1111/gfs.12261

Cruz, R.C., Guadagnin, D.L., 2010. Uma pequena história ambiental do Pampa: proposta de uma abordagem baseada na relação entre perturbação e mudança., in: Costa, B.P. da, Dieckel., M.E.G. (Eds.), A Sustentabilidade Da Região Da Campanha-RS: Práticas e Teorias a Respeito Das Relações Entre Ambiente, Sociedade, Cultura e Políticas Públicas. UFSM, PPG Geografia e Geociências, Santa Maria, pp. 155179 .

Fontana, D.C., Junges, A.H., Bremm, C., Schaparini, L.P., Mengue, V.P., Wagner, A.P.L., Carvalho, P., Fontana, D.C., Junges, A.H., Bremm, C., Schaparini, L.P., Mengue, V.P., Wagner, A.P.L., Carvalho, P., 2018. NDVI and meteorological data as indicators of the Pampa biome natural grasslands growth. Bragantia 77, 404-414. https://doi.org/10.1590/16784499.2017222

Gómez, M., Olioso, A., Sobrino, J.A., Jacob, F., 2005. Retrieval of evapotranspiration over the Alpilles/ReSeDA experimental site using airborne POLDER sensor and a thermal camera. Remote Sens. Environ. 96, 399-408.

Hoffmann, G.R., Arend, L.M., Silveira, J.C.B., Bellomo, H.R., 1997. Rio Grande do Sul: aspectos da geografia., 4th ed. Martins Livreiro, Porto Alegre.

IPCC, 2013. Climate Change 2013 - The Physical Science Basis. Cambridge University Press, Cambridge. https://doi.org/10.1017/CBO9781107415324

Jimenez-Munoz, J.C., Sobrino, J.A., Skokovic, D., Mattar, C., Cristobal, J., 2014. Land surface temperature retrieval methods from landsat- 8 thermal infrared sensor data. IEEE Geosci.

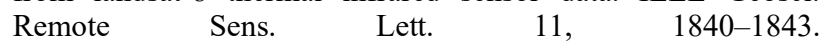
https://doi.org/10.1109/LGRS.2014.2312032

Liang, S., 2000. Narrowband to broadband conversions of land surface albedo I Algorithms. Remote Sens. Environ. 76, 213 238 .

Liang, S., Strahler, A.H., Walthall, C., 1998. Retrieval of land surface albedo from satellite observations: a simulation study. J. Appl. Meteorol. 38, 712-725.

Monteiro, P.F.C., Fontana, D.C., dos Santos, T.V., Roberti, D.R., 2014. Estimativa dos componentes do balanço de energia e da evapotranspiração para áreas de cultivo de soja no sul do brasil utilizando imagens do sensor TM landsat 5. Bragantia 73, 72-80. https://doi.org/10.15090/brag.2014.005

Neske, M.., Andrade, M.., Borba, M.F.., 2012. Capital Ecológicos e a Construção de Autonoma na Produção Familiar: o caso da pecuária familiar do Rio Grande do Sul. Cad. Ciência Tecnol. 29, 291-317.
Nimer, E., 1990. Geografia do Brasil: Regiao Sul. Rio de Janeiro.

Oliveira, L.B., Soares, E.M., Jochims, F., Tiecher, T., Marques, A.R., Kuinchtner, B.C., Rheinheimer, D.S., De Quadros, F.L.F., 2015. Long-Term Effects of Phosphorus on Dynamics of an Overseeded Natural Grassland in Brazil. Rangel. Ecol. Manag. 68, 445-452. https://doi.org/10.1016/j.rama.2015.07.012

OVERBECK, G.E., MÜLLER, S.C., Fidelis, A.T., PFADENHAUER, J., PILLAR, V., BLANCO, C.C., BOLDRINI, I.I., BOTH, R., FORNECK, E.D., 2007. Brazil's neglected biome: the South Brazilian Campos. Perspect. Plant Ecol. Evol. Syst. 9, 101-116.

OVERBECK, G.E., Podgaiski, L.R., MÜLLER, S.C.., 2015. Biodiversidade dos campos., in: PILLAR, V.., Lange, O. (Eds.), Campos Do Sul. Rede Campos Sulios, Porto Alegre, pp. 43-50.

Roerink, G.J., Su, Z., Menenti, M., 2000. S-SEBI: A simple remote sensing algorithm to estimate the surface energy balance. Phys. Chem. Earth, Part B Hydrol. Ocean. Atmos. 25, 147-157. https://doi.org/10.1016/S1464-1909(99)00128-8

Rouse, J.W., Hass, R.H., Schell, J.A., Deering, D.W., 1973. Monitoring vegetation systems in the great plains with ERTS. Third Earth Resour. Technol. Satell. Symp. 1, 309-317. https://doi.org/citeulike-article-id:12009708

Rubert, G.C., Roberti, D.R., Pereira, L.S., Quadros, F.L.F., Velho, H.F. de C., de Moraes, O.L.L., 2018. Evapotranspiration of the Brazilian Pampa biome: Seasonality and influential factors. Water (Switzerland) 10, 1-18. https://doi.org/10.3390/w10121864

Santos, T., Trevisan, R., 2009. Eucaliptos versus Bioma Pampa: compreendendo as diferenças entre lavouras de arbóreas e o campo nativo., in: Filho, A.T. (Ed.), Lavouras de Destruição: A (Im)Posição Do Consenso. Pelotas/RS, pp. 299-332.

Sobrino, J.A., Gómez, M., Jiménez-Muñoz, J.C., Olioso, A., 2007. Application of a simple algorithm to estimate daily evapotranspiration from NOAA-AVHRR images for the Iberian Peninsula. Remote Sens. Environ. 110, 139-148. https://doi.org/10.1016/j.rse.2007.02.017

Sobrino, J.A., Gómez, M., Jiménez-Muñoz, J.C., Olioso, A., Chehbouni, G., 2005. A simple algorithm to estimate evapotranspiration from DAIS data: Application to the DAISEX campaigns. J. Hydrol. 315, 117-125. https://doi.org/10.1016/j.jhydrol.2005.03.027

Sobrino, J.A., Li, Z.L., Stoll, M.P., Becker, F., 1996. Multichannel and multi-angle algorithms for estimating sea and land surface temperature with ATSR data. Int. J. Remote Sens. 17, 2089-2114.

Sobrino, J.A., Skoković, D., 2016. Permanent Stations for Calibration/Validation of Thermal Sensors over Spain. Data 1, 10. https://doi.org/10.3390/data1020010 